\title{
EFEITOS DE AMBIENTE SOBRE A CONTAGEM DE CÉLULAS SOMÁTICAS NO LEITE DE VACAS DA RAÇA HOLANDESA NO PARANÁ
}

\section{ENVIRONMENTAL EFFECTS ON SOMATIC CELL COUNT IN HOLSTEIN COWS AT PARANÁ STATE, BRAZIL}

\author{
André OSTRESKY \\ Orientador: Professor Titular José Sidney FLEMMING \\ Departamento de Zootecnia - UFPR
}

\begin{abstract}
RESUMO
A contagem de células somáticas (CCS) no leite é uma medida indireta da presença de infecção subclínica na glândula mamária de fêmeas bovinas, podendo ser utilizada para programas de controle de mastite, de pagamento de leite por qualidade e como parâmetro para legislação sanitária, entre outros. O presente estudo visou decompor os efeitos de alguns fatores de ambiente sobre a CCS, sobre o escore de células somáticas (ECS) e sobre o logaritmo de células somáticas (L2CS); estimar os componentes de variância e covariância para estas características; além de comparar o ECS e o L2CS com a CCS em amostras de leite de vacas da raça holandesa, no Paraná. Os dados foram obtidos de lactações encerradas de vacas sob controle leiteiro oficial pelo Programa de Análise de Rebanhos Leiteiros do Paraná (PARLPR) da APCBRH, de janeiro de 1994 a dezembro de 1998. Para a análise dos dados foi empregado o Método dos Quadrados Mínimos, utilizando-se o procedimento PROC GLM, do SAS. Foram analisadas 640.937 observações do controle mensal, de 40.333 vacas, pertencentes a 378 rebanhos. As médias e os respectivos desvios-padrões para a CCS, o ECS e o L2CS foram: $556.626 \pm 835.004$ células/ $\mathrm{mL} 4,461 \pm 1,789$ e $8,105 \pm 1,789$. Foram importantes fontes de

variação sobre as três características estudadas os efeitos de idade da vaca ao parto por ordem de lactação, estação de parto (exceto para a CCS), ano e mês de controle, estágio de lactação, idade da amostra, além do efeito de vaca. $O$ efeito de frequência de ordenha não foi significativo para nenhuma das três variáveis estudadas. Houve tendências de elevação nas médias ajustadas com o avançar da idade e da ordem de lactação. Os maiores valores de ECS e L2CS foram observados na primavera e os menores, no verão; porém, abril apresentou as maiores médias ajustadas para as três características e dezembro, para a CCS e agosto, para o ECS e o L2CS, as menores médias. Houve tendência a redução das CCS com o passar dos anos, mas 1996 apresentou os menores valores de ECS e L2CS. As curvas das três características durante a lactação iniciaram-se elevadas, reduziram-se até próximo a 40 dias e elevaram-se até o final da lactação. As médias ajustadas em função da idade da amostra, para a CCS, o ECS e o L2CS mostraram ligeiro crescimento até três dias e decresceram até aos quinze dias. E, por fim, o ECS mostrou ser um parâmetro mais seguro e preciso que a CCS para a população estudada.
\end{abstract}

\begin{abstract}
Somatic cell count (SCC) indicates the presence of intrammamary infection in cows. So it may be used for mastitis control, programs of milk quality payment and as a legal parameter of udder health. The objectives of this study were to evaluate the effects of some environmental factors on milk SCC, on somatic cell score (SCS) and on somatic cell logarithm (SCL), as well as to compare SCC and SCS in Holstein cows at Paraná State. A total of 640,937 monthly test-day records was obtained from 40,333 Holstein cows of 378 officially supervised herds by Holstein Association of Paraná State, from January 1994 to December

1998. The Least Square Method was applied, by SAS using PROC GLM. Mean and standard deviation concerning SCC, SCS and SCL were 556,626 $\pm 835,004$ cells $/ \mathrm{mL}, 4.461 \pm 1.789$ and 8.105 \pm 1.789 , respectively. Effects such age at calving per lactation calving season (except for SCC), month and year of test-day, as well as days-in-milk, age of milk sample and cows affected the three traits significantly $(P<0.01)$ in this study. The milking frequency effect was not significant $(P>0.05)$ for any of the traits. The statistical summary of SCS has proven to be more meaningful than the results concerning SCC.
\end{abstract}

